
Volodymyr Novikov ${ }^{2}$

\title{
SYNTHESIS OF SOME N OVEL THIAZOLO[4,5-b]PYRIDINES AND THEIR TUBERCULOSTATIC ACTIVITY EVALUATION
}

\author{
1Danylo Halytsky Lviv N ational Medical University; \\ 69, Pekarska str., 79010 Lviv, Ukraine; olena_klenina@yahoo.com \\ 2Lviv Polytechnic National University; 12, S. Bandery str., 79010 Lviv, Ukraine
}

Received: December 02, 2013 / Revised: J anuary 22, 2014 / Accepted: J une 12, 2014

(c) Chaban T., Klenina O., Drapak I., Ogurtsov V., Chaban I., Novikov V., 2014

\begin{abstract}
Structural modification of 5,7-dimethyl-6phenylazo- $3 H$-thiazolo[4,5-b]pyridin-2-one relative to the $3^{\text {rd }}$ position of basic heterocycle allows to use its functionalization as the convenient method for the synthesis of various derivatives and diversification of a series of $\mathrm{N}^{3}$ substituted thiazolo[4,5- $b$ ]pyridines. The efficient synthetic protocol for aminomethylation proceeding was developed which led to obtaining a series of novel 3-(phenylamino)-methyl derivatives of 5,7dimethyl-6-phenylazo-3H-thiazolo[4,5- $b$ ]pyridin-2-one.

The conditions for aminomethylation reaction allowing to obtain 3-(phenylamino)-methyl derivatives of 5,7dimethyl-6-phenylazo-3H-thiazolo[4,5- $b]$ pyridine-2-on, as well as hydrazide and arylidenhydrazide derivatives of (5,7-dimethyl-2-oxo-6-phenilazo-thiazolo[4,5-b] pyridine3 -yl) acetic acid with high yields have been developed. The tuberculostatic activity of the newly synthesized compounds was evaluated in vitro against Mycobacterium tuberculosis H37Rv stain using Lowenstein Jensen's egg medium.
\end{abstract}

Keywords: thiazolo[4,5- $b]$ pyridine derivatives, [3+3] cyclocondensation, organic synthesis, tuberculostatic activity.

\section{Introduction}

Mycobacterium tuberculosis infection remains a serious and evolving global health crisis. The inspection of incidence, prevalence, and mortality rates of tuberculosis (TB) in Ukraine is characterized by increasing frequency of mycobacteria drug resistance detection. An epidemic of untreatable extensively drugresistant TB rapid increasing provides an evidence that such resistivity is one of the most important medical and biological factors that significantly reduce the efficiency of newly diagnosed TB patients treatment standardized modes. This highlights the objectives for the development of innovative synthesis of compounds having improved tuberculostatic or bacteriostatic actions. The suggested approach will generate appropriate chemotherapy regimens and achieve termination of bacterial excretion at patients in a short time.

4-Azolidone core is considered to be the efficient scaffold for drug-like molecules design as the integral part of modern medicinal chemistry. 4-Thiazolidine moiety heterocycles and their pyridine fused analogues have acquired much importance because of their diverse pharmaceutical applications. For example, some of their derivatives are known as useful antimicrobial agents effective against a variety of human and veterinary pathogens [1]. Thiazolo[4,5-b]pyridines were also shown to possess strong inhibitory actions for $\mathrm{A} \beta 42$ fibrillization at the micromolar level for Alzheimer's disease treatment [2]. The significant antiexudative, antimicrobial and antioxidant effects of some thiazolo[4,5- $b]$ pyridine derivatives had been also reported [3-8]. Some of their analogues were recognized as $\mathrm{H} 3$ receptor antagonists [9, 10] or act as antagonists of metabotropic glutamate receptors 5 (mGluR5) [11] while other were revealed as potent inhibitors with respect to the receptors of the epidermal growth factor [12]. Some of them are able to activate the GK enzyme in vitro and significantly reduce glucose level [13].

The objective of the present study was synthesis of some novel $3 H$-thiazolo[4,5-b]pyridine-2-ones and their structural modification relative to their $\mathrm{N}^{3}$ position for further pharmacological screening for tuberculostatic activity in vitro evaluation. 


\section{Experimental}

\subsection{Reagents and Materials}

All chemicals were of analytical grade and commercially available. All reagents and solvents were used without further purification and drying.

\subsection{Experimental Chemical Section}

${ }^{1} \mathrm{HNMR}$ spectra of compounds in DMSO-d6 solution were registered on a spectrometer Varian Mercury VX-400 (400 MHz), internal reference TMS. The elemental analysis experimental data on contents of nitrogen and sulfur correspond to calculated ones $( \pm 0.3 \%)$.

5,7-Dimethyl-6-phenylazo-3H-thiazolo[4,5-b] pyridin-2-one (1). Sodium (2.5 g, $109 \mathrm{mmol})$ was dissolved in anhydrous methanol $(125 \mathrm{ml})$, and to the solution obtained 4-iminothiazolidin-2-one $(6.8 \mathrm{~g}, 50 \mathrm{mmol})$ and $\alpha$-phenylazoacetylacetone $(8 \mathrm{ml})$ were added at $293 \mathrm{~K}$. The mixture was left standing for 5 days with the intermittent stirring, then it was acidified with acetic acid to $\mathrm{pH} \sim 5$, five-fold diluted with water, the precipitate was filtered off, washed with water, and dried. Compound 1 was obtained after its recrystallization from toluene as a red crystalline powdered solid, well soluble in DMF, DMSO, sparingly soluble in other organic solvents. Yield $86 \%$. Melting point 531-532 K (decomp.). Elemental analysis $\mathrm{C}_{14} \mathrm{H}_{12} \mathrm{~N}_{4} \mathrm{OS}$. Determined, \%: N 19.77; S 11.41. Calculated, \%: N 19.70; S 11.28. ${ }^{1} \mathrm{H}$ NMR $\delta 2.42$ (s, 3H, $\left.\mathrm{CH}_{3}\right), 2.61\left(\mathrm{~s}, 3 \mathrm{H}, \mathrm{CH}_{3}\right), 7.59-7.61\left(\mathrm{~m}, 3 \mathrm{H}, \mathrm{C}_{6} \mathrm{H}_{5}\right)$, $7.80\left(\mathrm{~d}, 2 \mathrm{H}, J=8.0 \mathrm{~Hz}, \mathrm{C}_{6} \mathrm{H}_{5}\right), 12.78$ (s, 1H, NH).

General procedure of 5,7-dimethyl-6-phenylazo3H-thiazolo[4,5-b]pyridine-2-ones aminomethylation (2-5). Compound 1 (5mmol), appropriate amine $(5 \mathrm{mmol})$ and formaldehyde $(5 \mathrm{mmol})$ were added to dioxane $(20 \mathrm{ml})$. The reaction mixture was refluxed for $60 \mathrm{~min}$. After cooling the crystalline precipitate was filtered off, washed with ethanol and dried. The obtained compounds were re-crystallized from ethanol.

5,7-Dimethyl-3-[(methyl-phenylamino)-methyl]-6phenylazo-3H-thiazolo[4,5-b]pyridin-2-one (2). Yield $70 \%$. Melting point 463-464 K. Elemental analysis $\mathrm{C}_{22} \mathrm{H}_{21} \mathrm{~N}_{5} \mathrm{OS}$. Determined, \%: N 17.25; S 7.88. Calculated, $\%$ : N 17.36; S 7.95. ${ }^{1} \mathrm{H}$ NMR $\delta 2.41\left(\mathrm{~s}, 3 \mathrm{H}, \mathrm{CH}_{3}\right), 2.64$ (s, $\left.3 \mathrm{H}, \mathrm{CH}_{3}\right), 3.15\left(\mathrm{~s}, 3 \mathrm{H}, \mathrm{CH}_{3}\right), 5.64\left(\mathrm{~s}, 2 \mathrm{H}, \mathrm{CH}_{2}\right), 6.74(\mathrm{t}$, $\left.1 \mathrm{H}, J=8.2 \mathrm{~Hz}, \mathrm{CH}_{3}-\mathrm{N}-\underline{\mathrm{C}}_{6} \underline{\mathrm{H}}_{5}\right), 7.10(\mathrm{~d}, 2 \mathrm{H}, J=7.9 \mathrm{~Hz}$, $\left.\mathrm{CH}_{3}-\mathrm{N}-\underline{\mathrm{C}}_{6} \underline{\mathrm{H}}_{5}\right), 7.21$ (t, $\left.2 \underline{\mathrm{H}}, \bar{J}=7.9 \mathrm{~Hz}, \mathrm{CH}_{3}-\mathrm{N}-\underline{\mathrm{C}}_{6} \underline{\mathrm{H}}_{5}\right)$, 7.60-7.62 (m, 3H, $\left.\mathrm{C}_{6} \mathrm{H}_{5}\right), 7.87\left(\mathrm{~d}, 2 \mathrm{H}, J=8.5 \mathrm{~Hz}, \mathrm{C}_{6} \mathrm{H}_{5}\right)$.

5,7-Dimethyl-6-phenylazo-3-[(2-fluoromethylphenylamino-methyl]-3H-thiazolo[4,5-b]pyridin-2-one (3). Yield $75 \%$. Melting point 358-359 K. Elemental analysis $\mathrm{C}_{22} \mathrm{H}_{18} \mathrm{~F}_{3} \mathrm{~N}_{5} \mathrm{OS}$. Determined, \%: $\mathrm{N}$ 15.25; $\mathrm{S} 7.11$.
Calculated, \%: N 15.31; S 7.01. ${ }^{1} \mathrm{H}$ NMR $\delta 2.42(\mathrm{~s}, 3 \mathrm{H}$, $\left.\mathrm{CH}_{3}\right), 2.69$ (s, 3H, $\left.\mathrm{CH}_{3}\right), 5.61\left(\mathrm{~s}, 2 \mathrm{H}, \mathrm{CH}_{2}\right), 6.20(\mathrm{~s}, 1 \mathrm{H}$, $\mathrm{NH}), 6.86\left(\mathrm{t}, 1 \mathrm{H}, J=8.0 \mathrm{~Hz}, \mathrm{C}_{6} \mathrm{H}_{4}\right), 7.30(\mathrm{~d}, 1 \mathrm{H}$, $\left.J=8.2 \mathrm{~Hz}, \mathrm{C}_{6} \mathrm{H}_{4}\right), 7.47-7.49\left(\mathrm{~m}, 2 \mathrm{H}, \mathrm{C}_{6} \mathrm{H}_{4}\right), 7.61-7.63(\mathrm{~m}$, $\left.3 \mathrm{H}, \mathrm{C}_{6} \mathrm{H}_{5}\right), 7.89\left(\mathrm{~d}, 2 \mathrm{H}, J=8.5 \mathrm{~Hz}, \mathrm{C}_{6} \mathrm{H}_{5}\right)$.

3-[(3-Bromo-phenylamino)-methyl]-5,7-dimethyl6-phenylazo-3H-thiazolo[4,5-b]pyridin-2-one (4). Yield $68 \%$. Melting point 446-447 K. Elemental analysis $\mathrm{C}_{21} \mathrm{H}_{18} \mathrm{BrN}_{5} \mathrm{OS}$. Determined, \%: N 17.83; S 6.88 . Calculated, \%: N 14.95; S 6.85. ${ }^{1} \mathrm{H}$ NMR $\delta 2.44$ (s, 3H, $\left.\mathrm{CH}_{3}\right), 2.77$ (s, 3H, $\left.\mathrm{CH}_{3}\right), 5.42\left(\mathrm{~s}, 2 \mathrm{H}, \mathrm{CH}_{2}\right), 6.76(\mathrm{~s}, 1 \mathrm{H}$, $\mathrm{NH}), 6.93\left(\mathrm{~d}, 1 \mathrm{H}, J=9.7 \mathrm{~Hz}, \mathrm{C}_{6} \mathrm{H}_{4}\right), 7.03(\mathrm{t}, 1 \mathrm{H}, J=8.0$ $\left.\mathrm{Hz}, \mathrm{C}_{6} \mathrm{H}_{4}\right), 7.11\left(\mathrm{t}, 1 \mathrm{H}, J=8.0 \mathrm{~Hz}, \mathrm{C}_{6} \mathrm{H}_{4}\right), 7.61-7.64(\mathrm{~m}$, $\left.3 \mathrm{H}, \mathrm{C}_{6} \mathrm{H}_{5}\right), 7.77\left(\mathrm{~d}, 1 \mathrm{H}, J=7.5 \mathrm{~Hz}, \mathrm{C}_{6} \mathrm{H}_{4}\right), 7.89(\mathrm{~d}, 2 \mathrm{H}$, $\left.J=8.5 \mathrm{~Hz}, \mathrm{C}_{6} \mathrm{H}_{5}\right)$.

3-[(2-Chloro-phenylamino)-methyl]-5,7-dimethyl6-phenylazo-3H-thiazolo[4,5-b]pyridin-2-one (5). Yield $75 \%$. Melting point 483-484 K. Elemental analysis $\mathrm{C}_{21} \mathrm{H}_{18} \mathrm{ClN}_{5} \mathrm{OS}$. Determined, \%: $\mathrm{N}$ 16.83; $\mathrm{S} 7.58$. Calculated, \%: N 16.52; S 7.56. ${ }^{1} \mathrm{H}$ NMR $\delta 2.39$ (s, 3H, $\left.\mathrm{CH}_{3}\right), 2.71\left(\mathrm{~s}, 3 \mathrm{H}, \mathrm{CH}_{3}\right), 5.59\left(\mathrm{~s}, 2 \mathrm{H}, \mathrm{CH}_{2}\right), 6.14(\mathrm{~s}, 1 \mathrm{H}$, $\mathrm{NH}), 6.71\left(\mathrm{~s}, 1 \mathrm{H}, \mathrm{C}_{6} \mathrm{H}_{4}\right), 7.23-7.25\left(\mathrm{~m}, 3 \mathrm{H}, \mathrm{C}_{6} \mathrm{H}_{4}\right), 7.60$ ( $\left.\mathrm{s}_{\text {broad }}, 3 \mathrm{H}, \mathrm{C}_{6} \mathrm{H}_{5}\right), 7.86-7.87\left(\mathrm{~m}, 2 \mathrm{H}, \mathrm{C}_{6} \mathrm{H}_{5}\right)$.

Ethyl (5,7-dimethyl-2-oxo-6-phenylazo-3H-thiazolo [4,5-b]pyridin-3-yl)acetate (6). Potassium salt of 5,7dimethyl-6-phenylazo- $3 H$-thiazolo[4,5- $b$ ]pyridin-2-one (30 mmol) was completely dissolved in DMF $(20 \mathrm{ml})$ with heating. The solution obtained was treated with ethyl chloroacetate $(30 \mathrm{mmol})$. The reaction mixture was refluxed for $60 \mathrm{~min}$ observing considerable precipitating. The hot mixture was then filtered and the precipitate on the filter was washed with hot DMF. The filtrate was cooled to the temperature of about $323 \mathrm{~K}$, treated with water $(100 \mathrm{ml})$ at stirring and cooled to $285-288 \mathrm{~K}$. The precipitate was filtered off, washed with water, and dried. The obtained compounds were re-crystallized from acetic acid. Yield $66 \%$. Melting point 376-377 K. Elemental analysis $\mathrm{C}_{18} \mathrm{H}_{18} \mathrm{~N}_{4} \mathrm{O}_{3} \mathrm{~S}$. Determined, \%: N 14.85; S 8.52. Calculated, \%: N 15.12; S 8.66. ${ }^{1} \mathrm{H}$ NMR $\delta 1.23$ (t, 3H, $J=$ $\left.=7.0 \mathrm{~Hz}, \mathrm{OCH}_{2} \underline{\mathrm{CH}}_{3}\right), 2.48\left(\mathrm{~s}, 3 \mathrm{H}, \mathrm{CH}_{3}\right), 2.63(\mathrm{~s}, 3 \mathrm{H}$, $\left.\mathrm{CH}_{3}\right), 4.19-4.23\left(\mathrm{~m}, 2 \mathrm{H}, \mathrm{OCH}_{2} \mathrm{CH}_{3}\right), 4.82\left(\mathrm{~s}, 2 \mathrm{H}, \mathrm{N}-\underline{\mathrm{CH}}_{2}\right)$ 7.61-7.64 (m, 3H, $\left.\mathrm{C}_{6} \mathrm{H}_{5}\right), 7.89\left(\mathrm{~d}, 2 \mathrm{H}, J=6.2 \mathrm{~Hz}, \mathrm{C}_{6} \mathrm{H}_{5}\right)$.

(5,7-Dimethyl-2-oxo-6-phenylazo-thiazolo[4,5-

b]pyridine-3-yl)-acetic acid hydrazide (7). Compound 6 (20 mmol) was completely dissolved in ethanol $(8 \mathrm{ml})$. Hydrazine hydrate (30 mmol, $50 \%$ solution) was then added to the solution. The reaction mixture was refluxed for $12 \mathrm{~h}$. The precipitate that formed was filtered off, washed with water, and dried firstly at rt, then at $333 \mathrm{~K}$. The target compound was re-crystallized from butanol. Yield $65 \%$. Melting point 483-484 K. Elemental analysis $\mathrm{C}_{16} \mathrm{H}_{16} \mathrm{~N}_{6} \mathrm{O}_{2} \mathrm{~S}$. Determined, \%: $\mathrm{N}$ 23.40; $\mathrm{S} 9.06$. Calculated, \%: N 23.58; S 9.00. ${ }^{1} \mathrm{H}$ NMR $\delta 2.47$ (s, 3H, 
$\left.\mathrm{CH}_{3}\right), 2.63\left(\mathrm{~s}, 3 \mathrm{H}, \mathrm{CH}_{3}\right), 4.33\left(\mathrm{~s}, 2 \mathrm{H}, \mathrm{NH}_{2}\right), 4.60$ $\left(\mathrm{s}, 2 \mathrm{H}, \mathrm{CH}_{2}\right), 7.61-7.64\left(\mathrm{~m}, 3 \mathrm{H}, \mathrm{C}_{6} \mathrm{H}_{5}\right), 7.88(\mathrm{~d}, 2 \mathrm{H}$, $\left.J=8.5 \mathrm{~Hz}, \mathrm{C}_{6} \mathrm{H}_{5}\right), 9.42(\mathrm{~s}, 1 \mathrm{H}, \mathrm{NH})$.

General procedure for the synthesis of 5,7dimethyl-2-oxo-6-phenylazo-thiazolo[4,5-b]pyridine-3-ylacetic acid arylidene-hydrazides (8-14). Compound 7 (5 $\mathrm{mmol})$ was dissolved completely in ethanol $(30 \mathrm{ml})$. The solution obtained was treated with boiling appropriate aldehyde $(5 \mathrm{~mol})$ solution in methanol $(20 \mathrm{ml})$ with stirring. The reaction mixture was refluxed for $1 \mathrm{~h}$. The precipitate that formed was filtered off, washed with water, and dried firstly at room temperature, then at 373$383 \mathrm{~K}$. The target compounds 8-14 were obtained as orange or red crystalline powdered solids, well soluble in alcohols and acetic acid and insoluble in water.

2-(5,7-Dimethyl-2-oxo-6-phenylazo-thiazolo[4,5-

b]pyridin-3-yl)- $N$ '-[(4-fluorophenyl) methylidene]-acetohydrazide (8). Yield $90 \%$. Melting point 553-554 K. Elemental analysis $\mathrm{C}_{23} \mathrm{H}_{19} \mathrm{FN}_{6} \mathrm{O}_{4} \mathrm{~S}$. Determined, \%: $\mathrm{N}$ 18.25; S 6.96. Calculated, \%: N 18.17; S 6.93. ${ }^{1} \mathrm{H}$ NMR $\delta$ $2.55\left(\mathrm{~s}, 3 \mathrm{H}, \mathrm{CH}_{3}\right), 2.64\left(\mathrm{~s}, 3 \mathrm{H}, \mathrm{CH}_{3}\right), 5.19\left(\mathrm{~s}, 2 \mathrm{H}, \mathrm{CH}_{2}\right)$, $7.29\left(\mathrm{t}, 2 \mathrm{H}, J=7.6 \mathrm{~Hz}, \mathrm{C}_{6} \mathrm{H}_{4}\right), 7.63-7.66\left(\mathrm{~m}, 3 \mathrm{H}, \mathrm{C}_{6} \mathrm{H}_{5}\right)$, $7,82\left(\mathrm{t}, 2 \mathrm{H}, J=7.1 \mathrm{~Hz}, \mathrm{C}_{6} \mathrm{H}_{4}\right), 7.90(\mathrm{~d}, 2 \mathrm{H}, J=8.4 \mathrm{~Hz}$, $\left.\mathrm{C}_{6} \mathrm{H}_{5}\right), 8.09(\mathrm{~s}, 1 \mathrm{H}, \mathrm{CH}), 11.73(\mathrm{~s}, 1 \mathrm{H}, \mathrm{NH})$.

2-(5,7-Dimethyl-2-oxo-6-phenylazo-thiazolo[4,5b]pyridin-3-yl)-N'-[(4-chlorophenyl)methylidene]- acetohydrazide (9). Yield $77 \%$. Melting point $553-554 \mathrm{~K}$. Elemental analysis $\mathrm{C}_{23} \mathrm{H}_{19} \mathrm{ClN}_{6} \mathrm{O}_{2} \mathrm{~S}$. Determined, \%: $\mathrm{N}$ 17.70; S 6.51. Calculated, \%: N 17.55; S 6.69. ${ }^{1} \mathrm{H}$ NMR $\delta$ $2.55\left(\mathrm{~s}, 3 \mathrm{H}, \mathrm{CH}_{3}\right), 2.64\left(\mathrm{~s}, 3 \mathrm{H}, \mathrm{CH}_{3}\right), 5.19\left(\mathrm{~s}, 2 \mathrm{H}, \mathrm{CH}_{2}\right)$, $7.52\left(\mathrm{~d}, 2 \mathrm{H}, J=8.3 \mathrm{~Hz}, \mathrm{C}_{6} \mathrm{H}_{4}\right), 7.62-7.66\left(\mathrm{~m}, 3 \mathrm{H}, \mathrm{C}_{6} \mathrm{H}_{5}\right)$, $7.79\left(\mathrm{~d}, 2 \mathrm{H}, J=8.3 \mathrm{~Hz}, \mathrm{C}_{6} \mathrm{H}_{4}\right), 7.90(\mathrm{~d}, 2 \mathrm{H}, J=8.4 \mathrm{~Hz}$, $\left.\mathrm{C}_{6} \mathrm{H}_{5}\right), 8.01(\mathrm{~s}, 1 \mathrm{H}, \mathrm{CH}), 11.86(\mathrm{~s}, 1 \mathrm{H}, \mathrm{NH})$.

2-(5,7-Dimethyl-2-oxo-6-phenylazo-thiazolo[4,5b]pyridin-3-yl)-N'-[(4-bromophenyl) methylidene]- acetohydrazide (10). Yield $92 \%$. Melting point $548-549 \mathrm{~K}$. Elemental analysis $\mathrm{C}_{23} \mathrm{H}_{19} \mathrm{BrN}_{6} \mathrm{O}_{2} \mathrm{~S}$. Determined, \%: $\mathrm{N}$ 15.95; S 6.06. Calculated, \%: N 16.06; S 6.13. ${ }^{1} \mathrm{H}$ NMR $\delta$ $2.57\left(\mathrm{~s}, 3 \mathrm{H}, \mathrm{CH}_{3}\right), 2.64\left(\mathrm{~s}, 3 \mathrm{H}, \mathrm{CH}_{3}\right), 5.20\left(\mathrm{~s}, 2 \mathrm{H}, \mathrm{CH}_{2}\right)$, $7.62\left(\mathrm{~d}, 2 \mathrm{H}, J=7.0 \mathrm{~Hz}, \mathrm{C}_{6} \mathrm{H}_{4}\right), 7.65-7.70\left(\mathrm{~m}, 3 \mathrm{H}, \mathrm{C}_{6} \mathrm{H}_{5}\right)$, $7.71\left(\mathrm{~d}, 2 \mathrm{H}, J=7.0 \mathrm{~Hz}, \mathrm{C}_{6} \mathrm{H}_{4}\right), 7.90(\mathrm{~d}, 2 \mathrm{H}, J=8.5 \mathrm{~Hz}$, $\left.\mathrm{C}_{6} \mathrm{H}_{5}\right), 8.07(\mathrm{~s}, 1 \mathrm{H}, \mathrm{CH}), 11.86(\mathrm{~s}, 1 \mathrm{H}, \mathrm{NH})$.

2-(5,7-Dimethyl-2-oxo-6-phenylazo-thiazolo[4,5b]pyridin-3-yl)-N'-[(4-nitrophenyl) methylidene]-acetohydrazide (11). Yield $95 \%$. Melting point 535-536 K. Elemental analysis $\mathrm{C}_{23} \mathrm{H}_{19} \mathrm{~N}_{7} \mathrm{O}_{4} \mathrm{~S}$. Determined, \%: $\mathrm{N}$ 20.20; S 6.46. Calculated, \%: N 20.03; S 6.55. ${ }^{1} \mathrm{H}$ NMR $\delta$ $2.55\left(\mathrm{~s}, 3 \mathrm{H}, \mathrm{CH}_{3}\right), 2.63\left(\mathrm{~s}, 3 \mathrm{H}, \mathrm{CH}_{3}\right), 5.25\left(\mathrm{~s}, 2 \mathrm{H}, \mathrm{CH}_{2}\right)$, 7.59-7.66 (m, $\left.3 \mathrm{H}, \mathrm{C}_{6} \mathrm{H}_{5}\right), 7.88\left(\mathrm{~d}, 2 \mathrm{H}, J=8.5 \mathrm{~Hz}, \mathrm{C}_{6} \mathrm{H}_{5}\right)$, $8.00\left(\mathrm{~d}, 2 \mathrm{H}, J=7.1 \mathrm{~Hz}, \mathrm{C}_{6} \mathrm{H}_{4}\right), 8.20(\mathrm{~s}, 1 \mathrm{H}, \mathrm{CH}), 8.27(\mathrm{~d}$, $\left.2 \mathrm{H}, J=7.1 \mathrm{~Hz}, \mathrm{C}_{6} \mathrm{H}_{4}\right), 11.93(\mathrm{~s}, 1 \mathrm{H}, \mathrm{NH})$.

$N^{\prime}$-([4-(Dimethylamino)phenyl]methylidene)-2(5,7-dimethyl-2-oxo-6-phenylazo-thiazolo[4,5-b]pyridin3-yl)-acetohydrazide (12). Yield $80 \%$. Melting point 513$514 \mathrm{~K}$. Elemental analysis $\mathrm{C}_{25} \mathrm{H}_{25} \mathrm{~N}_{7} \mathrm{O}_{2} \mathrm{~S}$. Determined, \%:
N 20.72; S 6.50. Calculated, \%: N 20.11; S 6.58. ${ }^{1} \mathrm{H}$ NMR $\delta 2.51\left(\mathrm{~s}, 3 \mathrm{H}, \mathrm{CH}_{3}\right), 2.64\left(\mathrm{~s}, 3 \mathrm{H}, \mathrm{CH}_{3}\right), 2.99(\mathrm{~s}, 6 \mathrm{H}, \mathrm{N}-$ $\left.\mathrm{CH}_{3}\right), 5.13\left(\mathrm{~s}, 2 \mathrm{H}, \mathrm{CH}_{2}\right), 6.75\left(\mathrm{~d}, 2 \mathrm{H}, J=7.0 \mathrm{~Hz}, \mathrm{C}_{6} \mathrm{H}_{4}\right)$, $7.54\left(\mathrm{~d}, 2 \mathrm{H}, J=7.0 \mathrm{~Hz}, \mathrm{C}_{6} \mathrm{H}_{4}\right), 7.62-7.66\left(\mathrm{~m}, 3 \mathrm{H}, \mathrm{C}_{6} \mathrm{H}_{5}\right)$, $7.90\left(\mathrm{~d}, 2 \mathrm{H}, J=8.5 \mathrm{~Hz}, \mathrm{C}_{6} \mathrm{H}_{5}\right), 7.94(\mathrm{~s}, 1 \mathrm{H}, \mathrm{CH}), 11.45(\mathrm{~s}$, $1 \mathrm{H}, \mathrm{NH})$.

2-\{(2-[(5,7-Dimethyl-2-oxo-6-phenylazo-thiazolo [4,5-b]pyridin-3-yl)acetyl]hydrazinylidene)methyl\}-benzoic acid (13). Yield $90 \%$. Melting point 513-514 K. Elemental analysis $\mathrm{C}_{24} \mathrm{H}_{20} \mathrm{~N}_{6} \mathrm{O}_{4} \mathrm{~S}$. Determined, \%: N 17.30; S 6.45. Calculated, \%: N 17.20; S 6.56. ${ }^{1} \mathrm{H}$ NMR $\delta$ $2.55\left(\mathrm{~s}, 3 \mathrm{H}, \mathrm{CH}_{3}\right), 2.64\left(\mathrm{~s}, 3 \mathrm{H}, \mathrm{CH}_{3}\right), 5.20\left(\mathrm{~s}, 2 \mathrm{H}, \mathrm{CH}_{2}\right)$, $7.55\left(\mathrm{~d}, 2 \mathrm{H}, J=8.0 \mathrm{~Hz}, \mathrm{C}_{6} \mathrm{H}_{4}\right), 7.62-7.65\left(\mathrm{~m}, 3 \mathrm{H}, \mathrm{C}_{6} \mathrm{H}_{5}\right)$, $7.90\left(\mathrm{~d}, 2 \mathrm{H}, J=8.4 \mathrm{~Hz}, \mathrm{C}_{6} \mathrm{H}_{5}\right), 7.92\left(\mathrm{~s}, 1 \mathrm{H}, \mathrm{C}_{6} \mathrm{H}_{4}\right), 8.01(\mathrm{~s}$, $1 \mathrm{H}, \mathrm{CH}), 8.84\left(\mathrm{~s}, 1 \mathrm{H}, \mathrm{C}_{6} \mathrm{H}_{4}\right), 11.91(\mathrm{~s}, 1 \mathrm{H}, \mathrm{NH}), 13.28(\mathrm{~s}$, $1 \mathrm{H}, \mathrm{COOH})$.

$N^{\prime}-[(3,4-D i m e t h o x y p h e n y l) m e t h y l i d e n e]-2-(5,7-$ dimethyl-2-oxo-6-phenylazo-thiazolo[4,5-b]pyridin-3-yl) acetohydrazide (14). Yield $87 \%$. Melting point $531-532 \mathrm{~K}$. Elemental analysis $\mathrm{C}_{25} \mathrm{H}_{24} \mathrm{~N}_{6} \mathrm{O}_{4} \mathrm{~S}$. Determined, \%: $\mathrm{N}$ 16.52; S 6. 05. Calculated, \%: N 16.66; S 6.35. ${ }^{1} \mathrm{H}$ NMR $\delta$ $2.55\left(\mathrm{~s}, 3 \mathrm{H}, \mathrm{CH}_{3}\right), 2.64\left(\mathrm{~s}, 3 \mathrm{H}, \mathrm{CH}_{3}\right), 3.82\left(\mathrm{~d}, 6 \mathrm{H}, \mathrm{OCH}_{3}\right)$, $5.20\left(\mathrm{~s}, 2 \mathrm{H}, \mathrm{CH}_{2}\right), 7.02\left(\mathrm{~d}, 1 \mathrm{H}, J=9.1 \mathrm{~Hz}, \mathrm{C}_{6} \mathrm{H}_{3}\right), 7.22$ $\left(\mathrm{d}, 1 \mathrm{H}, J=9.0 \mathrm{~Hz}, \mathrm{C}_{6} \mathrm{H}_{3}\right), 7.40\left(\mathrm{~s}, 1 \mathrm{H}, \mathrm{C}_{6} \mathrm{H}_{3}\right), 7.62-7.66$ $\left(\mathrm{m}, 3 \mathrm{H}, \mathrm{C}_{6} \mathrm{H}_{5}\right), 7.90\left(\mathrm{~d}, 2 \mathrm{H}, J=8.4 \mathrm{~Hz}, \mathrm{C}_{6} \mathrm{H}_{5}\right), 8.00$ $(\mathrm{s}, 1 \mathrm{H}, \mathrm{CH}), 11.68(\mathrm{~s}, 1 \mathrm{H}, \mathrm{NH})$.

\subsection{Tuberculostatic Activity Evaluation}

The newly synthesized thiazolo[4,5-b]pyridine-2ones were examined in vitro for their tuberculostatic activity against Mycobacterium tuberculosis H37Rv strain fully sensitive to most presently known tuberculostatic drugs. Bacterial suspensions were prepared with 14-dayold cultures of H37Rv strain [14]. Polyethylene glycol 400 (PEG 400) was found to be the most suitable solvent for all novel compounds. Investigations were performed by a classical test-tube method of serial successive dilutions using solid Lowenstein Jensen's egg medium and the retardation of the growth rate was studied. The tuberculostatic concentrations of novel compounds were $6.25 \mu \mathrm{g} / \mathrm{ml}$. The compounds were incorporated into Lowenstein Jensen's egg medium and were inoculated with $0.2 \mathrm{ml}$ Mycobacterium tuberculosis $\mathrm{H} 37 \mathrm{Rv}$ strain suspension as inoculums in a $10-2 \mathrm{mg} / 5 \mathrm{ml}$ concentrated culture medium. The medium containing no investigated substances and containing isoniazid (INH) as reference drug in its minimum inhibitory concentration of $1.0 \mu \mathrm{g} / \mathrm{ml}$ was used for comparison.

The cultures were incubated at $310 \mathrm{~K}$ and examined at weekly intervals for 90 days. The retardation of the inoculums growth rate was studied by dynamic observations, the readings were done at $15,30,60$, and 90 days after inoculations. 


\section{Results and Discussion}

One of the efficient synthetic approaches to thiazolo[4,5- $b]$ pyridine fused heterocyclic system construction is based on $[3+3]$ cyclocondensation of 4iminothiazolidine-2-one [15], due to its N,Cbinucleophylic properties, with some dielectrophilic reagents like $\alpha$-phenylazoacetylacetone forming the above mentioned scaffold (1) [16] (Scheme 1). It was discovered that the high yield of the product in the developed protocol can be achieved at keeping the reagents mixture in methanol in the presence of sodium methylate.

The strong electrophilicity of hydrohen atom of $\mathrm{NH}$-group in the $3^{\text {rd }}$ position of the compound $\mathbf{1}$ allowed to use its functionalization as opportune method for the synthesis of various derivatives and diversification of a series of $\mathrm{N}^{3}$ substituted thiazolo[4,5-b]pyridines. Thus $\mathrm{NH}$-center with mobile hydrogen atom in the $3^{\text {rd }}$ position made it possible to involve compound $\mathbf{1}$ into aminomethylation proceeding, which led to obtaining a series of novel 3-(phenylamino)-methyl derivatives (2-5) (Scheme 2). The developed synthetic protocol was described via the one-pot multi-component reaction between formaldehyde, appropriate amines, and 5,7dimethyl-6-phenylazo- $3 H$-thiazolo[4,5- $b]$ pyridin-2-one (1). We discovered that the method offered high yields of products by introducing the dioxane reaction mixture at 60 minute refluxing.

Further studying of compound $\mathbf{1}$ properties showed the proton acidic character in the core heterocycle $\mathrm{N}^{3}$ position which promoted the tendency of its transformation into potassium salt. The obtained salt possessed nucleophilic properties and could be involved into alkylation reactions with ethyl chloroacetate in mild conditions leading to ethyl (5,7-dimethyl-2-oxo-6-phenylazo-3H-thiazolo[4,5-b]pyridin-3-yl)acetate (6) obtaining (Scheme 2 ).

Compound 6 represented a convenient intermediate to afford (5,7-dimethyl-2-oxo-6-phenylazothiazolo[4,5-b]pyridine-3-yl)-acetic acid hydrazide (7) as a precursor for more elaborate functionalizations of thiazolo[4,5- $b]$ pyridine-2-one moiety in its $\mathrm{N}^{3}$ position. The developed synthetic strategy showed that the target compound high yield may be achieved by the reaction proceeding in $96 \%$ ethanol medium by using $50 \%$ hydrazine hydrate solution with long-time boiling of the reaction mixture at hot water bath. Compound 7 hydrazide group allows transforming it into a series of the appropriate acetic acid arylidene-hydrazides (8-14). Treatment of compound 7 in $96 \%$ methanol solution with boiling appropriate aldehydes solution in methanol and the mixture refluxing for $1 \mathrm{~h}$. afforded the desired acetohydrazides in good yields (Scheme 3 ).

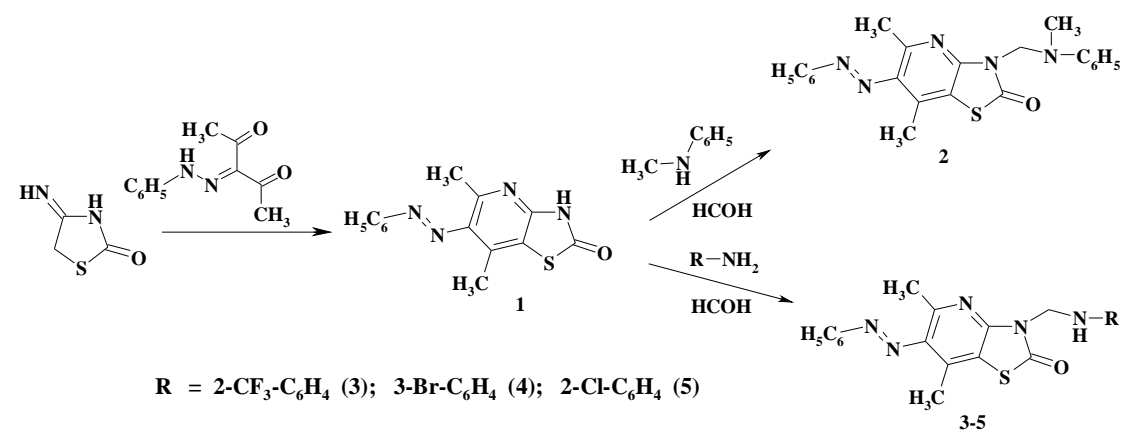

Scheme 1. Synthesis of 5,7-dimethyl-6-phenylazo-3H-thiazolo[4,5-b]pyridin-2-one (1) and its 3-(phenylamino)-methyl derivatives (2-5)<smiles>CCNNc1c(C)nc2c(sc(=O)n2CC(=O)OCC)c1C</smiles>

Scheme 2. Synthesis of ethyl (5,7-dimethyl-2-oxo-6-phenylazo-3H-thiazolo[4,5-b]pyridin-3-yl)acetate (6)<smiles>[Z]CN=CNC(=O)CN1C(=O)Sc2c(nc(C)c(NNC)c2C)N1CC(=O)NNC(=O)Cn1c(=O)sc2c(C)c(NNC(C)C)c(C)nc21</smiles>

$\mathbf{R}^{\prime}=4-\mathrm{F}-\mathrm{C}_{6} \mathrm{H}_{4}(8), 4-\mathrm{Cl}-\mathrm{C}_{6} \mathrm{H}_{4}(9), 4-\mathrm{Br}_{-} \mathrm{C}_{6} \mathrm{H}_{4}(10), 4-\mathrm{NO}_{2}-\mathrm{C}_{6} \mathrm{H}_{4}(11)$, 4- $\left(\mathrm{CH}_{3}\right)_{2}-\mathrm{N}-\mathrm{C}_{6} \mathrm{H}_{4}(12), 2-\mathrm{COOH}-\mathrm{C}_{6} \mathrm{H}_{4}(13), 3,4-(\mathrm{OMe})_{2}-\mathrm{C}_{6} \mathrm{H}_{3}(14)$

Scheme 3. Synthesis of (5,7-dimethyl-2-oxo-6-phenylazo-thiazolo[4,5-b]pyridine-3-yl)-acetic acid hydrazide (7) and its arylidene-hydrazide derivatives (8-14) 
The structures of the obtained compounds were confirmed by ${ }^{1} \mathrm{H}$ NMR spectroscopy and elemental analysis. The elemental analysis experimental data on contents of nitrogen and sulfur were within $\pm 0.3 \%$ as compared with the theoretical values. In the ${ }^{1} \mathrm{H}$ NMR spectral data, all protons were seen according to the expected chemical shift and integral values.

The ${ }^{1} \mathrm{H}$ NMR spectra of all compounds show the protons signals of methyl groups in pyridine ring as two singlets in the $\delta$ 2.33-2.57 and 2.45-2.64 ppm, respectively. Compounds 1-14 spectra show the signal of phenyl radical at $\mathrm{C}^{6}$ position as doublets, triplets, and multiplets at 7.61-7.92 ppm. The presence of the methylene group signals at 5.42-5.64 ppm for compounds 2-5 prove the aminomethylation reaction of the compound 1. Hydrazide group protons in the compound 7 show singlet signals at $9.42 \mathrm{mmp}$ for $\mathrm{NH}$ moiety and $4.33 \mathrm{mmp}$ for $\mathrm{NH}_{2}$ moiety, respectively. The methine functional group presence in compounds 8-14 is proved with singlet signals at 7.94-8.20 ppm, which is the evidence of nucleophilic addition with further cleavage reaction.

The in vitro tuberculostatic activity of 5,7dimethyl-6-phenylazo- $3 H$-thiazolo[4,5- $b$ ]pyridine-2-one derivatives was studied against Mycobacterium tuberculosis H37Rv stain using Lowenstein Jensen's egg medium by serial two-fold dilution and the retardation of the growth rate studied for 90 days at $333 \mathrm{~K}$. The tuberculostatic concentration was $6.25 \mu \mathrm{g} / \mathrm{ml}$. Compounds that inhibited the growth of M. tuberculosis N37Rv stain were considered to possess tuberculostatic activity in caseof growth inhibiting of tested tuberculous strains in relation to the isoniazid in its minimum inhibitory concentration had been estimated at the same level.

The results of the tuberculostatic activity evaluation of $3 H$-thiazolo[4,5- $b$ ]pyridine-2-one derivatives against M. tuberculosis H37Rv stain are summarized in Table 1.

The preliminary screening against Mycobacterium tuberculosis $\mathrm{H} 37 \mathrm{Rv}$ at $6.25 \mu \mathrm{g} / \mathrm{ml}$ revealed that almost all tested compounds exhibited low tuberculostatic activity, which was proved by their non-affecting the growth of $M$. tuberculosis. Compounds $\mathbf{8}$ and $\mathbf{9}$ were identified as the ones showing the highest inhibition against H37Rv stain (98 and $99 \%$, respectively). Our results indicated that the 2(5,7-dimethyl-2-oxo-6-phenylazo-thiazolo[4,5-b]pyridin- 3yl)- $\mathrm{N}$-[(phenyl)methylidene]-aceto-hydrazide derivatives having fluorine and chlorine atoms in $4^{\text {th }}$ position of $\mathrm{N}^{\prime}-[($ phenyl)methylidene substituent enhanced the antitubercular activity of the synthesized compounds. Thus compounds 8 and 9 were subjected to level 2 screening.

The minimal inhibitory concentrations values (MICs) were determined as minimum concentration inhibiting the growth of tested tuberculous strain in relation to the probe with no tested compound. The MIC test procedure was fulfilled just for compounds 8 and 9 whose stock solutions with the concentration of $6.25 \mu \mathrm{g} / \mathrm{ml}$ possessed biostatic (growth-stopping) activity against Mycobacterium tuberculosis $\mathrm{H} 37 \mathrm{Rv}$ stain at the level of more than $90 \%$ (Table 2).

Table 1

Tuberculostatic activity of novel thiazolo[4,5-b]pyridine-2-ones in the concentration of $6.25 \mu \mathrm{g} / \mathrm{ml}$ against Mycobacterium tuberculosis in vitro evaluation compared to that of isoniazid

\begin{tabular}{|c|c|c|c|c|c|c|c|c|c|}
\hline \multirow{2}{*}{$\begin{array}{c}\text { Compound } \\
\text { ID }\end{array}$} & \multicolumn{4}{|c|}{$\begin{array}{c}\text { The term of H37Rv stain inoculums growth } \\
\text { (days after inoculations) }\end{array}$} & \multirow{2}{*}{$\begin{array}{c}\text { Compound } \\
\text { ID }\end{array}$} & \multicolumn{4}{|c|}{$\begin{array}{c}\text { The term of H37Rv stain inoculums growth } \\
\text { (days after inoculations) }\end{array}$} \\
\hline & $20^{\text {th }}$ day & $30^{\text {th }}$ day & $60^{\text {th }}$ day & $90^{\text {th }}$ day & & $20^{\text {th }}$ day & $30^{\text {th }}$ day & $60^{\text {th }}$ day & $90^{\text {th }}$ day \\
\hline 1 & - & + & + & + & 9 & - & - & - & - \\
\hline 2 & - & + & + & + & 10 & - & + & + & + \\
\hline 3 & - & + & + & + & 11 & - & + & + & + \\
\hline 4 & - & + & + & + & 12 & - & + & + & + \\
\hline 5 & - & + & + & + & 13 & - & + & + & + \\
\hline 6 & - & + & + & + & 14 & - & + & + & + \\
\hline 7 & - & + & + & + & Isoniazid & - & - & - & - \\
\hline 8 & - & - & - & - & Control & + & + & + & + \\
\hline
\end{tabular}

Notes: (-) no growth; (+) inoculums moderate or intense growth.

Test results of the minimal inhibitory concentrations for compounds 8 and 9

\begin{tabular}{|c|c|c|}
\hline \multirow{2}{*}{ Compound ID } & \multicolumn{2}{|c|}{ Mycobacterium tuberculosis $\mathrm{H} 37 \mathrm{Rv}$} \\
\cline { 2 - 3 } & Growth inhibition in the concentration of $6.25 \mu \mathrm{g} / \mathrm{ml}, \%$ & MICs, $\mu \mathrm{g} / \mathrm{ml}$ \\
\hline $\mathbf{8}$ & 98 & 1.1 \\
\hline $\mathbf{9}$ & 99 & 0.85 \\
\hline Isoniazid & 98 & 1.0 \\
\hline
\end{tabular}


The proposed bacteriostatic activity tests results for the newly synthesized compounds and their tuberculostatic activity in vitro evaluation against Mycobacterium tuberculosis $\mathrm{H} 37 \mathrm{Rv}$ stain using Lowenstein Jensen's egg medium allowed to conclude that compounds 8 and 9 stock solutions with the concentration of $6.25 \mu \mathrm{g} / \mathrm{ml}$ showed the highest inhibition against H37Rv stain, which was determined to be at the level of isoniazid. The rest of the tested compounds did not affect the growth of M. tuberculosis.

\section{Conclusions}

Structural modification of 5,7-dimethyl-6phenylazo- $3 H$-thiazolo[4,5- $b$ ]pyridine-2-one derivatives was performed including the introduction of substituents diversity at the $\mathrm{N}^{3}$ position.

Pharmacological screening of novel 5,7-dimethyl6-phenylazo- $3 H$-thiazolo[4,5- $b]$ pyridine-2-one derivatives was performed for their tuberculostatic response evaluation, which allowed to identify two lead compounds showing inhibition against Mycobacterium tuberculosis H37Rv stain at the level of isoniazid. The proposed screening results provide an excellent starting point for rational design of the novel thiazolo[ $4,5-b]$ pyridine-2-ones and potential drug candidates development based on this scaffold.

\section{Acknowledgements}

Authors thank to Ph.D. Olena A. Tkach, Senior Research Fellow, Lviv Research Institute of Epidemiology and Hygiene by Ministry of Health of Ukraine for her assistance in tuberculostatic activity in vitro screening performed for novel thiazolopyridines.

\section{References}

[1] Saeyd H., Morsy E. and Kotb E.: Sci. Commun., 2010, 40, 2712. [2] Lee Y., Inhee M.-J. and Yoo K.: Bull. Korean Chem. Soc., 2008, 29, 2331.
[3] Chaban T., Ogurtsov V., Chaban I. et al.: Pharm. Rev., 2011, 2, 10.

[4] Ogurtsov V., Chaban T., Klenina O. et al.: Pharm. Rev., 2013, 1, 11 .

[5] Chaban T., Panchuk R., Klenina O. et al.: Biopolym. Cell., 2012, 25, 389.

[6] Chaban T., Ogurtsov V., Chaban I. et al.: Phosphorus Sulfur, 2013, 188, 1611.

[7] Klenina O., Drapak I., Chaban T. et al.: Chem. \& Chem. Techn., 2013, 7, 397.

[8] Marzoog S. and Al-Thebeiti: Farmaco, 2000, 55, 109.

[9] Walczynski K., Zuiderveld P. and Timmerman H.: Eur. J. Med. Chem., 2005, 40, 15.

[10] Rao A., Palani A., Chen X. et al.: Bioorg. Med. Chem. Lett., 2009, 19, 6176.

[11] Kulkarni S. and Newman A.: Bioorg. Med. Chem. Lett., 2007, 17, 2987.

[12] Lin R., Johnson S., Connolly P. et al.: Bioorg. Med. Chem. Lett., 2009, 19, 2333.

[13] Bebernitz G., Beaulieu V., Dale B. et al.: J. Med. Chem., 2009, $\mathbf{5 2}, 6142$.

[14] Stefanov O. (Ed.): Doclinichni Doslidzhenniya Likars'kych Zasobiv. Avicena, Kyiv 2001.

[15] Komaritsa I.: Khim. Geterotcycl. Soed., 1968, 3, 436

[16] Chaban T., Zimenkovskii B., Komaritsa J. et al.: Rus. J. Org. Chem., 2012, 48, 268.

\section{СИНТЕЗ ТА ВЛАСТИВОСТІ ДЕЯКИХ ТІАЗОЛО[4,5-b]ПІРИДИНІВ}

Анотація. Показано, щзо структурна модифікація 5,7диметил-6-фенілазо-3Н-тіазоло[4,5-b]піридин-2-ону за положенням 3 базового гетероциклу дає можливість використовувати його функиіоналізацію як зручний метод отримання різноманітних похідних та розщирити ряд $N^{3}$-заміщених тіазоло[4,5-b]піридинів. Визначено умови для проведення реакиії амінометилювання, яка дозволяе одержувати 3(феніламіно)-метил похідні 5,7-диметил-6-фенілазо-3Н-тіазоло[4,5-b]піридин-2-ону, а також оптимальні умови синтезу гідразиду та ариліденгідразидпохідних (5,7-диметил-2-оксо-6фенілазо-тіазоло[4,5-b]піридин-3-іл)-ацетатної кислоти 3 препаративно високими виходами. Для синтезованих речовин проведено in vitro скринінг протитуберкульозної активності. Вивчено антимікробну активність синтезованих речовин по відношенню до Mycobacterium tuberculosis H37Rv.

Ключові слова: похідні тіазоло[4,5-b]піридину, [3+3] циклоконденсачія, органічний синтез, протитуберкульозна активність. 